\title{
The flora of Dereiçi village (Yusufeli, Artvin, Turkey) and its surroundings
}

\author{
Dereiçi köyü (Yusufeli, Artvin, Türkiye) ve çevresinin florası
}

\author{
Emrah YÜKSEL ${ }^{a, *} \mathbb{C}^{-}$, Hayal AKYILDIRIM BEĞEN ${ }^{b}$ [ \\ aDepartment of Forest Engineering, Faculty of Forestry, Artvin Coruh University, 08000 Artvin, Turkey \\ ${ }^{b}$ Health Services Vocational School, Artvin Coruh University, Artvin, Turkey
}

\section{Article Info}

(C2018 Ali Nihat Gökyiğit Botanical Garden Aplication and Research Center of Artvin Coruh University.

*Corresponding author:

e-mail: emrahyuksel@artvin.edu.tr

ORCID: 0000-0002-8171-0383

\section{Article history}

Received: December 27, 2018

Received in revised form: December 29, 2018

Accepted: December 30, 2018

Available online: December 30, 2018

\section{Citation}

To cite this article: Yüksel $\mathrm{E}$, Akyıldırım Beğen H. (2018). The flora of Dereiçi village (Yusufeli, Artvin, Turkey) and its surroundings. Turk J Biod 1(1): 34-40.

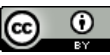
article under the CC BY license (http://creativecommons.org/licenses /by/4.0/).

\section{Keywords:}

Artvin, Dereiçi, endemism, flora, Yusufeli.

Anahtar kelimeler:

Artvin, Dereiçi, endemizm, flora, Yusufeli.

\begin{abstract}
The vascular flora of the Dereiçi Village and its environs (Yusufeli, Artvin, Turkey) was assessed between March and September 2017. It is located in the north-east of the Eastern Black Sea Region and is taken place in Colchic province of Euro-Siberian floristic area of Holarctic Region and lies between 650 and $2900 \mathrm{~m}$. In this study, 312 genera and 552 plant taxa were found in 87 families. Of these, 11 taxa belong to Pteridophyta, the remaining 541 taxa belong to Magnoliophyta. Magnoliophyta includes Pinidae with 6 taxa and Magnoliidae with 535 taxa. The biggest families identified were as follows: Asteraceae 58 taxa, Poaceae 49 taxa, Rosaceae 37 taxa, Lamiaceae 30 taxa, Fabaceae 25 taxa, Brassicaceae 24 taxa, Apiaceae 18 taxa, Boraginaceae 16 taxa, Caryophyllaceae 15 taxa and Ranunculaceae 14 taxa. The ratio of the phytogeographical regions of 266 taxa was determined as follows: Euro-Siberian with 216 taxa (\%39.1), Irano-Turanian with 42 taxa (\%7.6), Mediterranean with 8 taxa (\%1.5) and unidentified phytogeographic region with 286 taxa (\%51.8). The ratio of endemism is \% 5.4 with endemic taxa. Threat categories were proposed for 83 taxa (endemic and non-endemic rare plants) according to International Union for Conservation of Nature and Natural Resources (IUCN) Red List Categories.
\end{abstract}

Öz

Dereiçi köyü ve çevresinin (Yusufeli, Artvin, Türkiye) damarlı bitkiler florası, 2017 yılı Mart ve Eylül ayları arasında tespit edilmiştir. Alan, Doğu Karadeniz Bölgesi'nin Kuzeydoğu kısmında ve Holarktik bölgenin, Avrupa-Sibirya flora alanının Öksin kesiminin Kolşik altkesiminde bulunmakta olup 650 ile 2900 m yükseltiler arasında yer almaktadır. Bu araştırmada 87 familya, 312 cinse ait, 552 bitki taksonu saptanmıştır. Bunlardan 11'i Pteridophyta, kalan 541 taksonu Magnoliophyta bölümüne ilişkindir. Magnoliophyta bölümüne ilişkin taksonlardan 6 tanesi Pinidae ve 535 tanesi ise Magnoliidae alt sınıfında bulunmaktadır. Alandaki en fazla takson içeren familyalar şöyledir: Asteraceae 58 takson, Poaceae 49 takson, Rosaceae 37 takson, Lamiaceae 30 takson, Fabaceae 25 takson, Brassicaceae 24 takson, Apiaceae 18 takson, Boraginaceae 16 takson, Caryophyllaceae 15 takson ve Ranunculaceae 14 taksondur. Araştırmada, 266 taksonun fitocoğrafik bölgeleri saptanmış olup; 216 adet $(\% 39,1)$ AvrupaSibirya, 42 adet $(\% 7,6)$ İran-Turan, 8 adet $(\% 1,5)$ Akdeniz elementi ve 286 adet $(\% 51,8)$ fitocoğrafi bölgesi bilinmeyen takson bulunmaktadır. 30 adet takson endemik olup endemizm oranı \% 5,4'tür. IUCN tehlike kategorilerine göre 83 adet endemik ve endemik olmayan nadir bitki taksonunun tehlike kategorileri değerlendirilmiştir.

\section{INTRODUCTION}

Artvin is the richest city in terms of plant diversity and Yusufeli (Artvin, Turkey) province reflects this diversity with its geographic and geomorphological features. Naturally growing plants are distributed in this area and diversity of this plants related to climate, habitat and vegetation (Eminağaoğlu, 2015).

Dereiçi (Yusufeli) is located in the Caucasus AnatolianHyrcanian Temperate Forests classified as one of the 200 Global Ecoregions and in the North-eastern Anatolia 
Centre of Plant Diversity "SWA No.19" (WWF \& IUCN, 1994; Zazanashvili et al., 1999).

This study was carried out to contribute to the knowledge on the flora of Artvin. This region reflects the eastern part of the rich plant composition of the Black Sea region. So it was focused to the new floristic taxa, the endemic and rare plants, and to enrich the Herbarium of Artvin Coruh University (ARTH) with the new data obtained from this study.

Some flora studies in nearby areas were published by Anşin (1979, 1983), Güner (1983), Güner at al. (1987), Vural (1996), Anşin et al. (2000), Eminağaoğlu and Anşin (2002, 2003, 2004, 2005), Eminağaoğlu et al. (2007, 2012, 2018), Eminağaoğlu (2009, 2015) and Yüksel and Eminağaoğlu (2017).

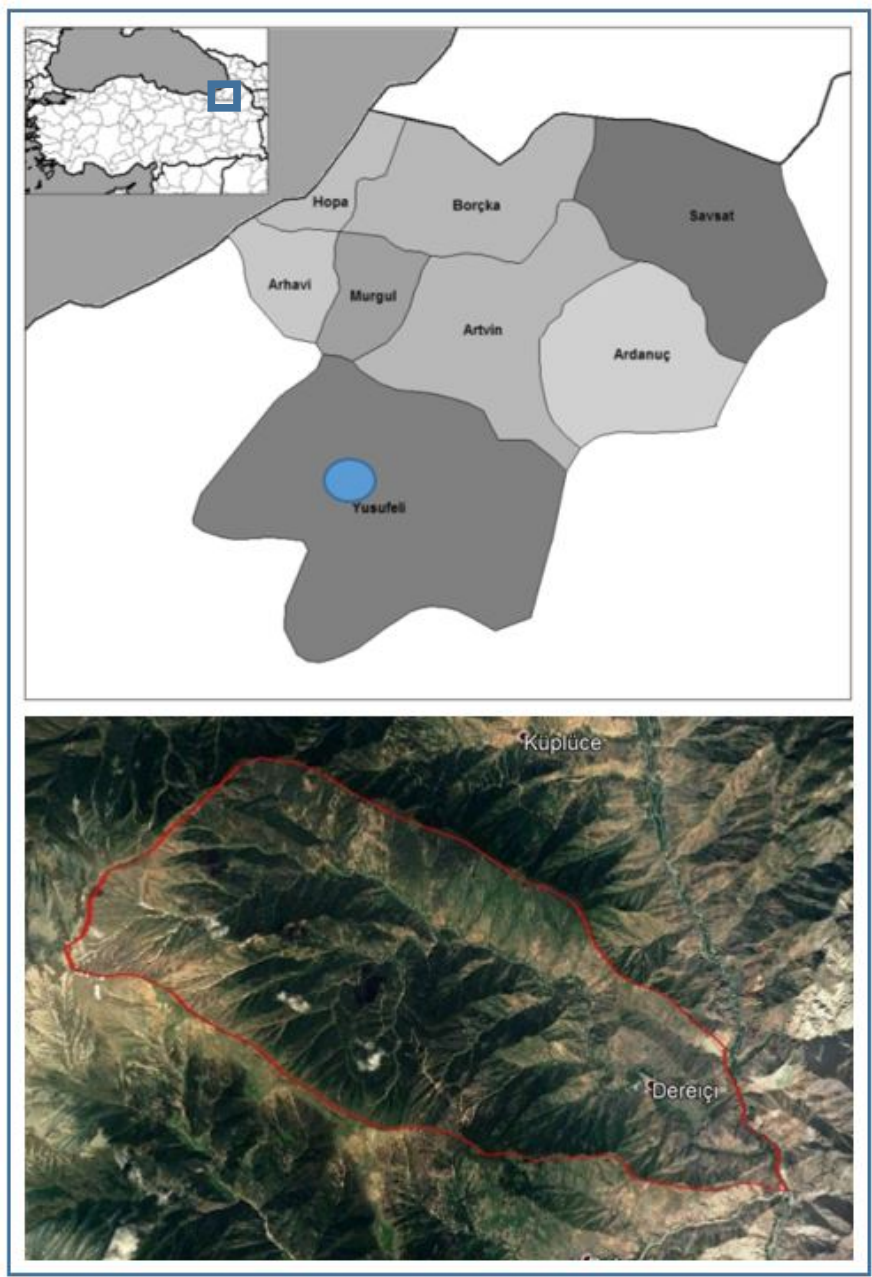

Figure 1. Map of the research area.
According to the Davis's grid system, the research area is in the A9 square, and within the Colchic province of the Euro-Siberian floristic area in the Holarctic region (Davis et al., 1971; Eminağaoğlu, 2015). The research area is located between long $41^{\circ} 32^{\prime} 26^{\prime \prime}-41^{\circ} 24^{\prime} 45^{\prime \prime} E$ and lat $40^{\circ} 51^{\prime} 17^{\prime \prime}-40^{\circ} 53^{\prime} 45^{\prime \prime} \mathrm{N}$, and its elevation ranges between 650 and $2900 \mathrm{~m}$ (Figure 1).

Climatological data were provided from Yusufeli Meteorological station. The average rainfall is $275,4 \mathrm{~mm}$ (annual) and the average temperature is $14.13^{\circ} \mathrm{C}$ in the research area (DMi, 2018) (Table 1). The climatic diagram was prepared using Walter's method (Walter, 1956). Most rainy season in winter, the driest of seasons in summer (Figure 2).

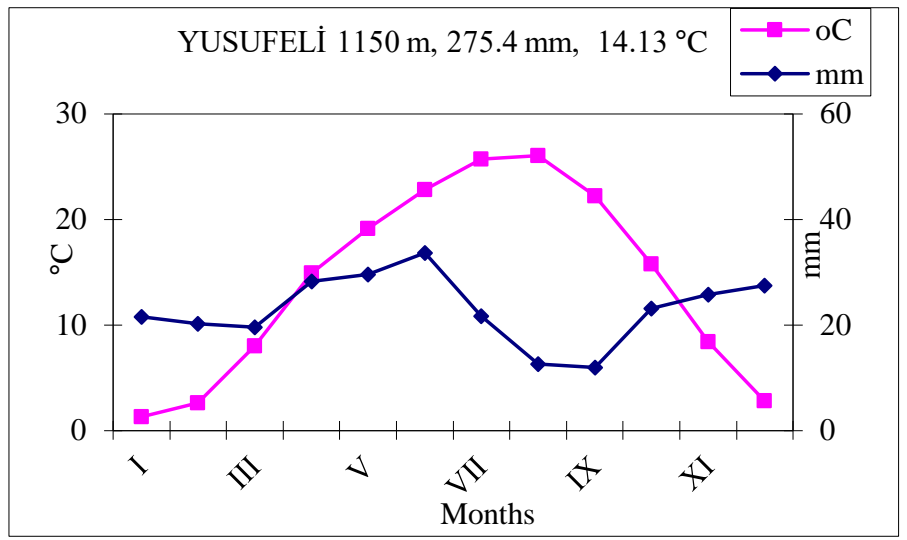

Figure 2. Climatic diagram of Yusufeli.

\section{MATERIAL AND METHOD}

A total of 1781 plant specimens were collected from Dereiçi Village of Yusufeli District (Artvin ) during MarchSeptember 2017. Three plant samples collected were placed in the Artvin Coruh University Herbarium (ARTH). They were photographed, and their GPS coordinates were recorded. The plant specimens were identified by using identification keys given in Flora of Turkey (Davis, 1965 - 1985; Davis et al., 1988; Güner et al., 2000), Flora of USSR (Komarov, 1934-1978) and other floras (Ketzkhoveli \& Gagnidze, 1971-2001). At least 1 sample for each taxon was prepared by herbarium techniques and kept at the Herbarium of Artvin Coruh University (ARTH), Artvin, Turkey. All rare plants are listed in the Appendix. According to IUCN risk categories, threatened 
Table 1. The average climatic values in Yusufeli (DMi, 2018).

\begin{tabular}{|c|c|c|c|c|c|c|c|c|c|c|c|c|c|}
\hline \multirow[t]{2}{*}{ Meteorological Data } & \multicolumn{13}{|c|}{ Months } \\
\hline & 1 & 2 & 3 & 4 & 5 & 6 & 7 & 8 & 9 & 10 & 11 & 12 & Average Annual \\
\hline Mean Temparature $\left({ }^{\circ} \mathrm{C}\right)$ & 1,3 & 2,6 & 8 & 14,9 & 19,1 & 22,8 & 25,7 & 26 & 22,2 & 15,8 & 8,4 & 2,8 & 14,13 \\
\hline Total rainfall (mm) & 21,6 & 20,2 & 19,6 & 28,2 & 29,6 & 33,6 & 21,7 & 12,6 & 12,0 & 23,1 & 25,8 & 27,4 & 275,4 \\
\hline
\end{tabular}

categories were given (Ekim et al., 2000, 2014; IUCN, 2018). The phytogeographical regions of the taxa were evaluated according to Davis (1965 - 85) and Davis et al., (1988). The plant names were given the accepted names using Türkiye Bitkileri Listesi, Damarlı Bitkiler (Güner et al., 2012), The International Plant Names Index (IPNI, 2012) and The Plant List (2013). The abbreviations used in the appendix and in the text are as follows: LC: Least concern; CR: Critically endangered; VU: Vulnerable; NT: Near threatened;.NE: Not evaluated; EN: Endangered.

\section{RESULTS AND DISCUSSION}

A total of 552 taxa from 87 families were identified. 11 of them belong to Pteridophyta and the remaining 541 taxa were Magnoliophyta, which included 6 taxa from the Pinidae and 535 taxa from the Magnoliidae (Table 2).

Table 2. The dispersion of taxa into large taxonomical groups.

\begin{tabular}{lcc}
\hline & $\begin{array}{c}\text { Number of } \\
\text { Families }\end{array}$ & Number of Taxa \\
\hline Pteridophyta & 5 & 11 \\
Magnoliophyta & 82 & 541 \\
\hline Pinidae & 2 & 6 \\
$\quad$ Magnoliidae & 80 & 535 \\
\hline Total & 87 & 552 \\
\hline
\end{tabular}

The ratio of endemism is $5.4 \%$, with 30 taxa. According to IUCN risk categories (Ekim et al., 2000; IUCN, 2018), totally 83 rare taxa ( 30 endemic taxa and 53 nonendemic) were evaluated. The distribution of the threat categories is as follows: 4 endemic taxa in CR [Campanula troegerae Damboldt, Helichrysum artvinense P.H.Davis \& Kupicha, Saxifraga artvinensis V.A.Matthews, Stachys choruhensis
Kit Tan \& Sorger], 9 endemic [Acer cappadocicum Gled. subsp. divergens (K.Koch ex Paxton) A.E.Murray, Alyssum artvinense N.Busch., Bupleurum schistosum Woronow, Chesneya elegans Fomine, Gypsophila simulatrix Bornm. \& Woronow, Eminium koenenianum Lobin \& P.C.Boyce, Salvia huberi Hedge, Sempervivum staintonii Muirhead, Sorbus caucasica Zinserl. var. yaltirikii Gökşin] and 1 nonendemic [Knautia montana DC.] taxa in EN, 5 endemic [Bupleurum brachiatum K.Koch ex Boiss., Cirsium pseudopersonata Boiss. \& Balansa ex Boiss. subsp. pseudopersonata, Papaver lateritium K.Koch subsp. lateritium, Primula longipes Freyn \& Sint., Psephellus taochius Sosn.] and 6 nonendemic [Crocus scharojanii Rupr., Cyanus cheiranthifolius (Willd.) Soják var. purpurascens (DC.) Wagenitz, Cynoglossum holosericeum Steven, Gypsophila tenuifolia M.Bieb., Lilium kesselringianum Miscz., Primula elatior (L.) Hill subsp. pseudoelatior (Kusn.) W.W.Sm \& Forrest] taxa in VU, 1 endemic [Ballota rotundifolia K.Koch] and 1 nonendemic [Astrantia maxima Pall. subsp. maxima] taxa in NT, 11 endemic [Alcea calvertii (Boiss.) Boiss., Allium djimilense Boiss. ex Regel, Campanula betulifolia K.Koch, Cerastium armeniacum Gren., Elymus lazicus (Boiss.) Melderis, Euonymus latifolius (L.) Mill. subsp. cauconis Coode \& Cullen, Galium margaceum Ehrend. \& Schönb.-Tem., Linaria genistifolia (L.) Mill. subsp. confertiflora (Boiss.) P.H.Davis, Salvia rosifolia Sm., Taraxacum turcicum Soest, Tragopogon aureus Boiss.] and 20 nonendemic [Abies nordmanniana (Steven) Spach subsp. nordmanniana, Alnus glutinosa (L.) Gaertn. subsp. barbata (C.A.Mey) Yalt., Betula pendula Roth, Carpinus betulus L., C. orientalis Mill., Daphne glomerata Lam, Heracleum cyclocarpum C. Koch, Juniperus oxycedrus L. subsp. oxycedrus, J. excelsa M.Bieb., J. foetidissima Willd., Ostrya carpinifolia Scop., Picea orientalis (L.) Peterm., Populus tremula L., Salix alba L., S. caprea L., S. excelsa S.G.Gmel., 
S. triandra L., Sempervivum transcaucasicum Muirhead, Sorbus subfusca (Ledeb. Ex Nordm.) Boiss., Swertia iberica Fisch. ex C.A.Mey.] taxa in LC, 25 nonendemic [Androsace intermedia Ledeb., Campanula alliariifolia Willd., C. lactiflora M.Bieb., Cirsium caucasicum Petr., C. obvallatum (M.Bieb.) M.Bieb., Crocus vallicola Herb., Delphinium flexuosum M.Bieb., Draba hispida Willd., $D$. siliquosa M.Bieb., Epilobium colchicum Albov, Fritillaria latifolia Willd., Geranium ibericum Cav. subsp. ibericum, G. psilostemon Ledeb., Origanum rotundifolium Boiss., Pedicularis wilhelmsiana Fisch. Ex M.Bieb., Potentilla elatior Willd. ex Schltdl., Primula meyeri Rupr., Rhamnus pallasii Fisch. \& C.A.Mey., Rhododendron caucasicum Pall., Rhynchocorys stricta Albov, Ribes petraeum Wulfen, Sedum spurium M.Bieb., Sorbus caucasica Zinserl. var. caucasica, Scutellaria pontica K.Koch, Thymus praecox Opiz subsp. grossheimii (Ronniger) Jalas var. grossheimii] taxa in NE.

The study area is included in the Colchic sub-section of Euxine section of the Euro-Siberian phytogeographic area of the Holarctic region in terms of plant geography. The reason of this plant diversity is that the area is located close to one of the 144 Important Plant Areas of Turkey "Important Plant Areas Yalnızçam mountains" and "Coruh Valley Important Plant Areas" (Özhatay et al., 2005).

The endemic elements and phytogeographical percentages are given in Table 3. Endemism ratio is similar with other floristic studies (Güner, 1983; Güner et al., 1987; Eminağaoğlu \& Anşin, 2003; Eminağaoğlu et al., 2007, 2018; Eminağaoğlu, 2009; Yüksel \& Eminağaoğlu, 2017).
The research area is located in a transitional zone among this three phytogeographic region. The Euro-Siberian elements (39.1\%) seem to be dominant in all areas studied, the Irano-Turanian elements (7.6\%) come second. When the distribution of taxa determined by phytogeographic regions is examined, it is seen that the European -Siberian elements are more in the all works. Mediterranean taxa were determined in some regions like other studies with low number of taxa (Table 3).

The largest families in terms of number of genera were, Poaceae (28), Asteraceae (26), Lamiaceae (22), Rosaceae (18), Brassicaceae (17), Boraginaceae (17), Fabaceae (16), Apiaceae (14), Caryophyllaceae (11), Ranunculaceae (10). The richest families in terms of number of species were Asteraceae (58), Poaceae (49), Rosaceae (37), Lamiaceae (30), Fabaceae (25), Brassicaceae (24), Apiaceae (18), Boraginaceae (16), Caryophyllaceae (15), Ranunculaceae (14). The total ratio of the 10 major families is $51.8 \%$, with the remaining families comprising $48.2 \%$ (Table 4 ). The major family order in our study is concordant with the Flora of Turkey (Güner et al., 2000).

A comparison of families in terms of the largest number of species found in this study and in previous studies carried out in nearby regions is given in Table 4. The data of this research are similar with those of other similar studies. As a result of climatic and habitat changes, plant families might differ and show diversity. In this study, Campanula (10), Geranium (9), Poa (9) are the richest genera with their taxon number.

Table 3. The phytogeographical spectra of the taxa (\%) in this study and other studies.

\begin{tabular}{|l|l|l|l|l|l|l|l|l|}
\hline & Study Area & $\begin{array}{l}\text { Eminağaoğlu } \\
\text { et al. (2018) }\end{array}$ & $\begin{array}{l}\text { Yüksel and } \\
\text { Eminağaoğlu } \\
(2017)\end{array}$ & $\begin{array}{l}\text { Eminağaoğlu } \\
(2009)\end{array}$ & $\begin{array}{l}\text { Eminağaoğlu } \\
\text { et al. (2007) }\end{array}$ & $\begin{array}{l}\text { Eminağaoğlu } \\
\text { \& Anşin } \\
(2003)\end{array}$ & $\begin{array}{l}\text { Güner et al. } \\
(1987)\end{array}$ & $\begin{array}{l}\text { Güner } \\
(1983)\end{array}$ \\
\hline Taxa & 552 & 566 & 651 & 459 & 963 & 769 & 1430 & 1024 \\
\hline Euro-Siberian & 39.1 & 22.90 & 50.08 & 17.2 & 48.90 & 35.60 & 48.25 & 40.82 \\
\hline Irano-Turanian & 7.6 & 14 & 2.92 & 17.6 & 2.00 & 6.90 & 5.73 & 4.00 \\
\hline Mediterranean & 1.5 & 2.40 & 0.77 & 2.6 & 2.00 & 2.20 & 3.01 & 1.46 \\
\hline Endemism & 5.4 & 3.20 & 2.92 & 7.6 & 1.10 & 7.40 & 18.46 & 20.02 \\
\hline
\end{tabular}


Table 4. Comparison of the ten families containing the most species in studies conducted in nearby regions (\%).

\begin{tabular}{|c|c|c|c|c|c|c|c|c|}
\hline Families & $\begin{array}{l}\text { Study } \\
\text { Area }\end{array}$ & $\begin{array}{l}\text { Eminağaoğlu } \\
\text { et al. (2018) }\end{array}$ & $\begin{array}{l}\text { Yüksel and } \\
\text { Eminağaoğlu } \\
\text { (2017) }\end{array}$ & $\begin{array}{l}\text { Eminağaoğlu } \\
\text { (2009) }\end{array}$ & $\begin{array}{l}\text { Eminağaoğlu } \\
\text { et al. (2007) }\end{array}$ & $\begin{array}{l}\text { Eminağaoğlu } \\
\text { \& Anşin } \\
(2003)\end{array}$ & $\begin{array}{l}\text { Güner et al. } \\
\text { (1987) }\end{array}$ & Güner (1983) \\
\hline Asteraceae & 10.5 & 6.3 & 12.0 & 8.1 & 11.5 & 9.5 & 12.5 & 13.2 \\
\hline Poaceae & 8.9 & 6.7 & 6.8 & 8.7 & 7.0 & 4.9 & 10.7 & 6.5 \\
\hline Rosaceae & 6.7 & 6.7 & 5.9 & 3.0 & 6.1 & 6.5 & 5.0 & 5.9 \\
\hline Lamiaceae & 5.4 & 6.7 & 4.3 & 4.5 & 4.5 & 5.5 & 4.3 & 4.3 \\
\hline Fabaceae & 4.5 & 5.6 & 4.6 & 8.1 & 6.0 & 8.7 & 4.8 & 5.8 \\
\hline Brassicaceae & 4.4 & 4.5 & 4.3 & 5.0 & 4.6 & 6.4 & 4.4 & 4.2 \\
\hline Apiaceae & 3.3 & 2.8 & 2.6 & 4.1 & 2.5 & 1.7 & 3.3 & 3.2 \\
\hline Boraginaceae & 2.9 & 3.8 & 2.8 & 3.4 & 3.6 & 3.3 & - & 2.7 \\
\hline Caryophyllaceae & 2.7 & 3.8 & 3.2 & 5.0 & 3.0 & 3.7 & 3.9 & 4.0 \\
\hline Ranunculaceae & 2.5 & 3.5 & 3.1 & 1.3 & 3.2 & 4.2 & - & 2.7 \\
\hline
\end{tabular}

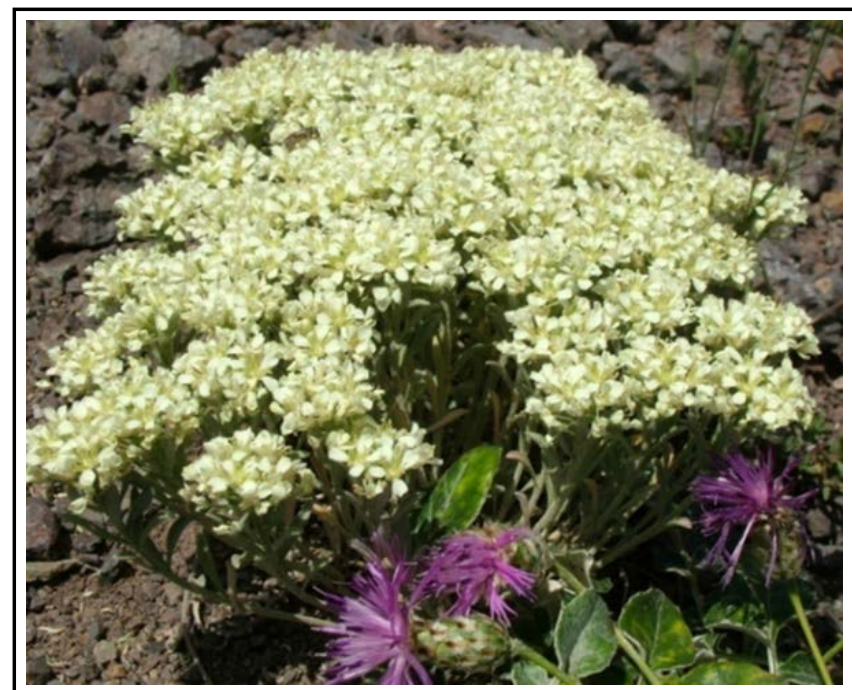

Alyssum artvinense

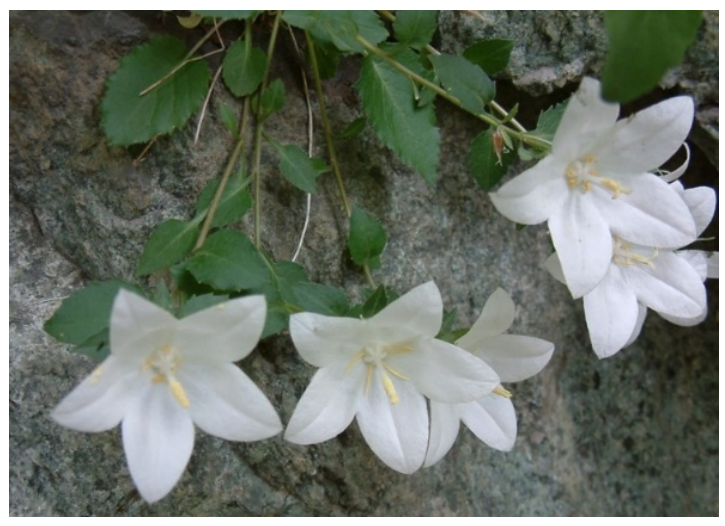

Campanula troegerae

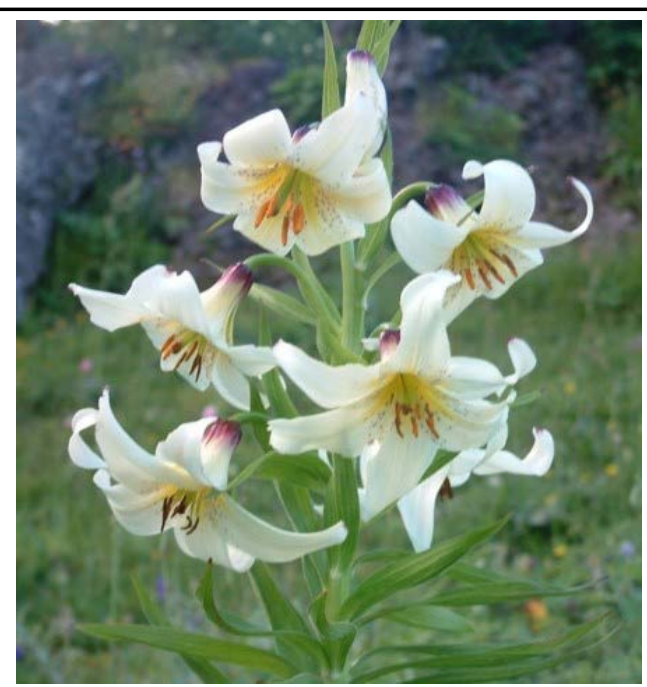

Lilium kesselringianum

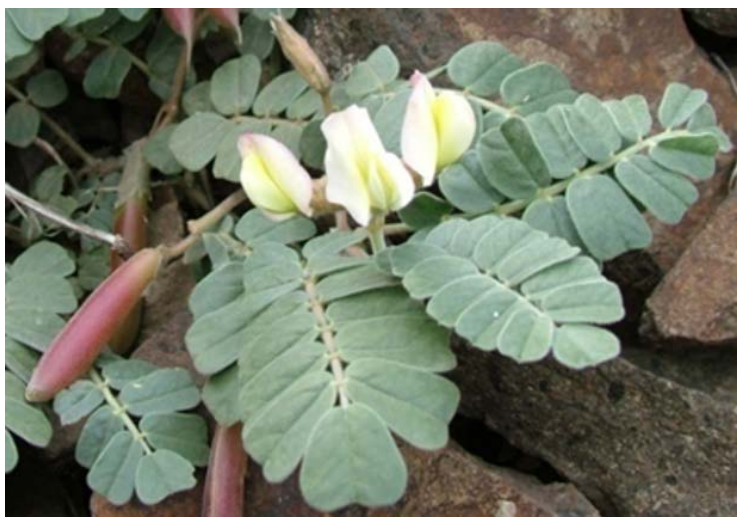

Chesneya elegans

Figure 3. Some important endemic and non endemic taxa (Photo: Ö.Eminağaoğlu) 
Campanula troegerae, Helichrysum artvinense, Acer cappadocicum subsp. divergens, Saxifraga artvinensis, Stachys choruhensis, Sorbus caucasica var. yaltirikii which have limited distribution area in this region. Considering this biological richness, the research area should be protected (Figure 3).

\section{CONCLUTION}

Biodiversity in Yusufeli is under the threat of various factors; investment projects, dam construction, illegal cutting, road construction. The study area has been exposed to these factors. For this reason, similar activities to be carried out in Dereiçi and its surroundings may cause detrimental impact on habitat changes and result in the destruction of rare species in the area.

These areas should be conservation status. The construction of the dam in the vicinity of the site threatens the existing vegetation diversity directly and indirectly. Populations that will be damaged by dam water or dam construction should be transported to the areas determined by ex situ conservation. Bupleurum schistosum and Chesneya elegans which are distributed at lower altitudes and the majority of their populations will remain under the dam water mirror, may be damaged by road and dam construction activities. For this reason, especially the rare and endemic areas of this plant species should be protected and their generations should be protected (Figure 3).

\section{Acknowledgements}

We would like to thank the Ministry of Agriculture and Forestry for its financial support.

\section{REFERENCES}

Anşin R (1979). Trabzon-Meryemana Araştırma Ormanı Florası ve Saf Ladin Meşcerelerinde Floristik Araştırmalar. Trabzon: Karadeniz Gazetecilik ve Matbaacllık Press, 234p. (in Turkish)

Anşin R (1983). Türkiye'nin Flora Bölgeleri ve Bu Bölgelerde Yayılan Asal Vejetasyon Tipleri (The Floristic Regionsand the Major Vegetation Types of Turkey). KTÜ Orman Fakültesi Dergisi 6(2): 318-339. (in Turkish)

Anşin R, Özkan ZC, Abay G, Eminağaoğlu Ö (2000). New Floristic Records From A8 Artvin. Ot Sistematik Botanik Dergisi 4(1): 95-98.
Davis PH (ed) (1965-1985). Flora of Turkey and the East Aegean Islands. Vols. 1-9. Edinburgh: Edinburgh University Press.

Davis PH, Harper PC, Hedge IC (1971). Plant Life of South West Asia. Edinburg:The Botanical Society of Edinburg. 335p.

Davis PH, Mill RR, Tan K, (eds) (1988). Flora of Turkey and the East Aegean Islands. Vol. 10. Edinburgh:Edinburgh University Press.

DMi (2018). Artvin Meteoroloji Müdürlüğü 1970-2018 Yılları Arası Yusufeli illçesi İklim Verileri. Ankara.

Ekim T, Koyuncu M, Vural M, Duman H, Aytaç Z, Adıgüzel N (2000). Türkiye Bitkileri Kırmızı Kitabı, Eğrelti ve Tohumlu Bitkiler (Red Data Book of Turkish Plants, Pteridophyta and Spermatophyta). Ankara: Barışcan Ofset, 246p.

Ekim T, Terzioğlu S, Eminağaoğlu Ö, Coşkunçelebi K (2014). Turkey. In: Solomon J, Schulkina T, Schatz GE (eds), Red List of the Endemic Plants of Caucasus: Armenia, Azerbaijan, Georgia, Iran, Russia, and Turkey. Monographs in Systematic Botany from the Missouri Botanical Garden (MSB) Saint Louis: 125. Missouri Botanical Garden Press, pp: 209-242.

Eminağaoğlu Ö (2009). The Plant Diversity Of Tekkale Çevreli And Cemketen Villages (Yusufeli, Artvin). Batumi Botanical Garden Bulletin 33: 152-159.

Eminağaoğlu Ö (ed) (2015). Artvin'in Doğal Bitkileri. İstanbul: Promat, 456p. (in Turkish).

Eminağaoğlu Ö, Anşin R (2002). A9 (Artvin) Karesi İçin Yeni Floristik Kayitlar. Kafkas Üniversitesi Artvin Orman Fakültesi Dergisi 3(1): 96-108. (in Turkish).

Eminağaoğlu Ö, Anşin R (2003). The Flora of Hatila Valley National Park and its close Environs (Artvin). Turkish Journal of Botany 27(1): 127.

Eminağaoğlu Ö, Anşin R (2004). Flora of the Karagöl-Sahara National Park (Artvin) and its Environs. Turkish Journal of Botany 28(6): 557590.

Eminağaoğlu Ö, Anşin R (2005). The Flora of Cerattepe Meydanlar Demirci Gavur Creek and Near Environment in Artvin. Istanbul Üniversitesi Orman Fakültesi Dergisi 55(2): 31-46.

Eminağaoğlu Ö, Anşin R, Kutbay HG (2007). Forest Vegetation of Karagöl Sahara National Park (Artvin, Turkey). Turkish Journal of Botany 31(5): 421-449.

Eminağaoğlu Ö, Özkaya M S, Akpulat HA (2012). A New Record for the Flora of Turkey: Sorbus caucasica var. caucasica (Rosaceae). Turkish Journal of Botany 36(4): 426-426.

Eminağaoğlu Ö, Yüksel E, Akyıldırım Beğen $H$ (2018). Flora of the Hod Valley (Artvin, Turkey). International Journal of Ecosystems and Ecology Science-IJEES 8 (2): 273-282.

Güner A (1983). Kaçkar Dağlarının Kuzey Yamacının Florası. TÜBITAK, TBAG-463, Ankara. (in Turkish).

Güner A, Aslan S, Ekim T, Vural M, Babaç MT (eds) (2012). Türkiye Bitkileri Listesi (Damarlı Bitkiler). İstanbul: Nezahat Gökyiğit Botanik Bahçesi ve Flora Araştırmaları Derneği Yayını. (in Turkish).

Güner A, Özhatay N, Ekim T, Başer KHC (2000). Flora of Turkey and the East Aegaen Islands. Vol. XI, (Supplement II), Edinburgh: Edinburgh University Press.

Güner A, Vural M \& Sorkun K (1987). Rize Florası, Vejetasyonu ve Yöre Ballarının Polen Analizi. TÜBiTAK, TBAG-650, Ankara. (in Turkish).

IPNI (2015). International Plant Name Index. Published on the Internet. http://www.ipni.org. Downloaded on 13 September 2018.

IUCN (2018). The IUCN Red List of Threatened Species. Version 20182. http://www.iucnredlist.org. Downloaded on 13 August 2018.

Ketzkhoveli NN \& Gagnidze RI (eds.) (1971-2001). Georgian Flora (Flora of Georgia). Vols. 1-13. Metsniereba, Tbilisi, Georgia. 
Komarov VL (1934-78). Flora of the U.S.S.R., Vol. 1-30. Israel Program for Scientific Translations, Jerusalem.

Özhatay N, Byfield A, Atay S (2005). Türkiye'nin 122 Önemli Bitki Alanı. İstanbul: WWF Turkey, pp. 476. (in Turkish)

PL (2013). The Plan List, Version 1.1. Published on the Internet. http://www.theplantlist.org. Downloaded 12 October 2018.

Vural M (1996). Rize'nin Yüksek Dağ Vejetasyonu. Turkish Journal of Botany 20: 83-102.

Walter H (1956). Kurak Zamanların Tesbitinde Esas Olarak Kullanılacak Klimogram, (Çev. S.Uslu). iü Orman Fakültesi Dergisi 8(2): 95-104.

APPENDIX: IUCN risk categories of endemic and nonendemic rare plants in the research area.

\begin{tabular}{|c|c|c|}
\hline TAXA & ENDEMISM & $\begin{array}{l}\text { IUCN } \\
(2018) \\
\end{array}$ \\
\hline Campanula troegerae Damboldt & Endemic & $\mathrm{CR}$ \\
\hline Helichrysum artvinense P.H.Davis \& Kupicha & Endemic & $\mathrm{CR}$ \\
\hline Saxifraga artvinensis V.A.Matthews & Endemic & CR \\
\hline Stachys choruhensis Kit Tan \& Sorger & Endemic & $\mathrm{CR}$ \\
\hline Acer cappadocicum Gled. subsp. divergens & & \\
\hline (K.Koch ex Paxton) A.E.Murray & Endemic & EN \\
\hline Alyssum artvinense N.Busch. & Endemic & EN \\
\hline Bupleurum schistosum Woronow & Endemic & EN \\
\hline Chesneya elegans Fomine & Endemic & EN \\
\hline Gypsophila simulatrix Bornm. \& Woronow & Endemic & EN \\
\hline Eminium koenenianum Lobin \& P.C.Boyce & Endemic & EN \\
\hline Salvia huberi Hedge & Endemic & EN \\
\hline Sempervivum staintonii Muirhead & Endemic & EN \\
\hline Sorbus caucasica Zinserl. var. yaltirikii Gökşin & Endemic & EN \\
\hline $\begin{array}{l}\text { Bupleurum brachiatum K.Koch ex Boiss. } \\
\text { Cirsium pseudopersonata Boiss. \& Balansa ex }\end{array}$ & Endemic & VU \\
\hline Boiss. subsp. pseudopersonata & Endemic & VU \\
\hline Papaver lateritium K.Koch subsp. lateritium & Endemic & VU \\
\hline Primula longipes Freyn \& Sint. & Endemic & VU \\
\hline Psephellus taochius Sosn. & Endemic & VU \\
\hline Ballota rotundifolia K.Koch & Endemic & NT \\
\hline Alcea calvertii (Boiss.) Boiss. & Endemic & LC \\
\hline Allium djimilense Boiss. ex Regel & Endemic & LC \\
\hline Campanula betulifolia K.Koch & Endemic & LC \\
\hline Cerastium armeniacum Gren. & Endemic & LC \\
\hline Elymus lazicus (Boiss.) Melderis & Endemic & LC \\
\hline $\begin{array}{l}\text { Euonymus latifolius (L.) Mill. subsp. cauconis } \\
\text { Coode \& Cullen }\end{array}$ & Endemic & LC \\
\hline 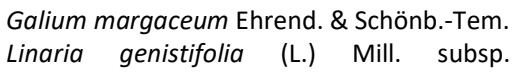 & Endemic & LC \\
\hline confertiflora (Boiss.) P.H.Davis & Endemic & LC \\
\hline Salvia rosifolia Sm. & Endemic & LC \\
\hline Taraxacum turcicum Soest & Endemic & LC \\
\hline Tragopogon aureus Boiss. & Endemic & LC \\
\hline Knautia montana DC. & Non Endemic & EN \\
\hline Crocus scharojanii Rupr. & Non Endemic & VU \\
\hline $\begin{array}{l}\text { Cyanus cheiranthifolius (Willd.) Soják var. } \\
\text { purpurascens (DC.) Wagenitz }\end{array}$ & Non Endemic & VU \\
\hline Cynoglossum holosericeum Steven & Non Endemic & VU \\
\hline Gypsophila tenuifolia M.Bieb. & Non Endemic & VU \\
\hline Lilium kesselringianum Miscz. & Non Endemic & VU \\
\hline $\begin{array}{l}\text { Primula elatior (L.) Hill subsp. pseudoelatior } \\
\text { (Kusn.) W.W.Sm \& Forrest }\end{array}$ & Non Endemic & VU \\
\hline Astrantia maxima Pall. subsp. maxima & Non Endemic & NT \\
\hline
\end{tabular}

WWF \& IUCN (1994). Centres of Plant Diversity. A Guide and Strategy for Their Conservation. Vol. 1. Cambridge: IUCN Publications Unit.

Yüksel E, Eminağaoğlu Ö (2017). Flora Of The Kamilet Valley (Arhavi, Artvin, Turkey). International Journal of Ecosystems and Ecology Science-IJEES 7(4): 905-914.

Zazanashvili N, Sanadiradze G, Bukhnikashvili A (1999). Caucasus. In: Mittermeier RA, Meyers N, Robles Gil P, Mittermeier CG (eds). Hotspots: Earth's Biologically Richest and Most Endangered Terrestrial Ecoregions. Mexico: CEMEX. pp. 268-277.
Abies nordmanniana (Steven) Spach subsp. nordmanniana

Alnus glutinosa (L.) Gaertn. subsp. barbata (C.A.Mey) Yalt.

Betula pendula Roth

Carpinus betulus L.

Carpinus orientalis Mill.

Daphne glomerata Lam

Heracleum cyclocarpum C. Koch

Juniperus oxycedrus L. subsp. oxycedrus

Juniperus excelsa M.Bieb.

Juniperus foetidissima Willd.

Ostrya carpinifolia Scop.

Picea orientalis (L.) Peterm.

Populus tremula L.

Salix alba L.

Salix caprea $\mathrm{L}$.

Salix excelsa S.G.Gmel.

Salix triandra $\mathrm{L}$.

Sempervivum transcaucasicum Muirhead

Sorbus subfusca (Ledeb. Ex Nordm.) Boiss.

Swertia iberica Fisch. ex C.A.Mey.

Androsace intermedia Ledeb.

Campanula alliariifolia Willd.

Campanula lactiflora M.Bieb.

Cirsium caucasicum Petr.

Cirsium obvallatum (M.Bieb.) M.Bieb.

Crocus vallicola Herb.

Delphinium flexuosum M.Bieb.

Draba hispida Willd.

Draba siliquosa M.Bieb.

Epilobium colchicum Albov

Fritillaria latifolia Willd.

Geranium ibericum Cav. subsp. ibericum

Geranium psilostemon Ledeb.

Origanum rotundifolium Boiss.

Pedicularis wilhelmsiana Fisch. Ex M.Bieb.

Potentilla elatior Willd. ex Schltdl.

Primula meyeri Rupr.

Rhamnus pallasii Fisch. \& C.A. Mey.

Rhododendron caucasicum Pall.

Rhynchocorys stricta Albov

Ribes petraeum Wulfen

Sedum spurium M.Bieb.

Sorbus caucasica Zinserl. var. caucasica

Scutellaria pontica K.Koch

Thymus praecox Opiz subsp. grossheimii

(Ronniger) Jalas var. Grossheimii

\begin{tabular}{ll} 
Non Endemic & LC \\
Non Endemic & LC \\
Non Endemic & LC \\
Non Endemic & LC \\
Non Endemic & LC \\
Non Endemic & LC \\
Non Endemic & LC \\
Non Endemic & LC \\
Non Endemic & LC \\
Non Endemic & LC \\
Non Endemic & LC \\
Non Endemic & LC \\
Non Endemic & LC \\
Non Endemic & LC \\
Non Endemic & LC \\
Non Endemic & LC \\
Non Endemic & LC \\
Non Endemic & LC \\
Non Endemic & LC \\
Non Endemic & LC \\
Non Endemic & NE \\
Non Endemic & NE \\
Non Endemic & NE \\
Non Endemic & NE \\
Non Endemic & NE \\
Non Endemic & NE \\
Non Endemic & NE \\
Non Endemic & NE \\
Non Endemic & NE \\
Non Endemic & NE \\
Non Endemic & NE \\
Non Endemic & NE \\
Non Endemic & NE \\
Non Endemic & NE \\
Non Endemic & NE \\
Non Endemic & NE \\
Non Endemic & NE \\
Non Endemic & NE \\
Non Endemic & NE \\
Non Endemic & NE \\
Non Endemic & NE \\
Non Endemic & NE \\
Non Endemic & NE \\
Non Endemic & NE \\
& \\
Non Endemic & NE \\
\hline &
\end{tabular}

